\title{
BIOCONVERSION OF PETROLEUM HYDROCARBONS IN SOIL USING APPLE FILTER CAKE
}

\author{
M. Cecilia Medaura*; Eduardo C. Ércoli. \\ Laboratorio de Bioprocesos, Facultad de Ingeniería, Universidad Nacional de Cuyo, Mendoza, Argentina
}

Submitted: July 02, 2007; Returned to authors for corrections: February 21, 2008; Approved: July 14, 2008.

\begin{abstract}
The aim of this study was to investigate the feasibility of using apple filter cake, a fruit-processing waste to enhance the bioremediation of petroleum contaminated soil. A rotating barrel system was used to study the bioconversion of the xenobiotic compound by natural occurring microbial population. The soil had been accidentally polluted with a total petroleum hydrocarbon concentration of 41,000 ppm. Although this global value was maintained during the process, microbial intervention was evidenced through transformation of the petroleum fractions. Thus, fractions that represent a risk for the environment (GRO, Gasoline Range Organics i.e., C6 to C10-12; DRO, Diesel Range Organics i.e., C8-12 to C24-26 and RRO, Residual Range Organics i.e., C25 to C35) were significantly reduced, from $2.95 \%$ to $1.39 \%$. On the contrary, heavier weight fraction from $\mathrm{C} 35$ plus other organics increased in value from $1.15 \%$ to $3.00 \%$. The noticeable diminution of low molecular weight hydrocarbons content and hence environmental risk by the process plus the improvement of the physical characteristics of the soil, are promising results with regard to future application at large scale.
\end{abstract}

Key-words: apple filter cake, bioconversion, bioremediation, petroleum contaminated soil.

\section{INTRODUCTION}

Oil and oil distillate spills are frequent contamination events that affect vast land areas, causing damages to the ecology and the economy of rural regions. Thus, the development of ecological, compatible and inexpensive technologies aimed to remediate hydrocarbon contamination, becomes a priority. These techniques have to be designed and tested thoroughly before applying them to a field problem. Usually, hydrocarboncontaminated soils lack organic matter of botanical origin and have low microbial activity. The addition of a fruit-processing waste can be beneficial since it represents a source of cosubstrates, nutrients and microorganisms and ameliorates the structure and water-retaining capacity of the soil in favour of aerobic conditions. The incorporation of exogenous microorganisms might accelerate the degradation of contaminants in soil (27). Aerobic metabolism generates heat, resulting in significant temperature increases caused by changes in the microbial population and physiology in the mixture. Temperature affects not only the physiological reaction rates and population dynamics of microbes, but also most of the physicochemical characteristics of the environment $(2,3)$.

The selection of waste substrates involves the difficulty of finding a residue with the right balance of nutrients to support optimal growth and production (21). For the experiment of this study, we proposed the utilization of apple filter cake for the bioremediation of petroleum contaminated soil because it is an industrial waste of the impacted zone. Although this material may have other industrial uses, large amounts are generated, what makes it easily available. Transportation distances from apple manufactory to soil treatment areas are short and this lowers its cost. Even though addition of organic material to contaminated soil is not a new concept for improving its remediation $(20,22)$, the use of local waste materials in Argentina has not often been tested before. Since the use of local available organic wastes appears to be a promising cheap alternative to accelerate TPH decomposition in contaminated soil, the success of this approach is not only important locally, but it could be applied in other regions and with the use of other wastes. The aim of this study was thus to investigate the feasibility of

*Corresponding Author. Mailing address: Laboratorio de Bioprocesos, Facultad de Ingeniería, Universidad Nacional de Cuyo, 5500, Mendoza, Argentina. Tel.: +54 2614494187 int.2136; fax: +54 261 4380120. E-mail: mmedaura@uncu.edu.ar 
employing apple filter cake to enhance the bioremediation of a soil accidentally polluted with petroleum using a rotating barrel system. This preliminary test would help to determine the operational requirements of the system in order to attain target end-point concentrations and its practical application on largescale treatment.

\section{MATERIALS AND METHODS}

\section{Experimental Design}

A rotating barrel of 200 litres capacity was specially constructed for this experiment. A $0.5 \mathrm{~mm}$ (pore size) net set at the bottom of the barrel defined a compartment for possible leachates collection added with a purge valve. The composition of the mixture consisted of $70 \mathrm{~kg}$ of contaminated soil and $30 \mathrm{~kg}$ of apple filter cake. The soil was loamy sand with a residual concentration of 41,000 ppm of TPH (Total Petroleum Hydrocarbons). It was air dried and sieved with a $2 \mathrm{~mm}$ grid. Hydrocarbon (HC) fractions extractable with dichloromethane from dry soil were: GRO: 0.13\% (Gasoline Range Organics; i.e., C6 to C10-12); DRO: 2.59\% (Diesel Range Organics; i.e., C8-12 to $\mathrm{C} 24-26$ ); RRO: $1.38 \%$ (Residual Range Organics; comprising $0.23 \%$ from $\mathrm{C} 25$ up to $\mathrm{C} 35$ and $1.15 \%$ compounds of more than C35 and other organics). Aromatic compounds as benzene, toluene, ethylbenzene, xilene (BTEX), trimethylbenzene, methylethylbenzene, propylbenzene and naphthalene (aromatics up to C10) were determined individually. All of them were below the detection limit of $0.01 \mathrm{ppm}$. The content of volatile compounds shorter than $\mathrm{C} 10$ was $20 \mathrm{ppm}$.

Chemical analysis indicated that total nitrogen content of the soil was $300 \mathrm{ppm}$, phosphorous content was $6.2 \mathrm{ppm}, 6.58 \%$ (wt/wt) of moisture, saturation point $35 \%$ and $\mathrm{pH}=7.2$. The concentration of heavy metals was under the guideline values (13).

The apple filter cake was obtained from a cider factory of Tunuyán, Mendoza, Argentina. Its humidity content was $85 \%$. The initial $\mathrm{pH}$ value of 4 was modified by the addition of $3.33 \%$ (wt./wt.) of $\mathrm{Ca}(\mathrm{OH})_{2}$ to reach a value of $\mathrm{pH}=7$. To estimate the HC-like contribution to the mixture made by the apple filter cake, it was treated identically as the soil for TPH extraction. The extractable compounds with dichloromethane from the dry material expressed as hydrocarbon fractions were: GRO: $0.00 \%$; DRO: $16.00 \%$; RRO: $43.00 \%$ and $41.00 \%$ of 35 and other organic compounds.

The extractable compounds with dichloromethane from the mixture expressed as TPH were 40,000 ppm (4\% wt/wt.). The expression as hydrocarbon fractions was: GRO: 0.04\%; DRO: 1.97\%; RRO: $0.32 \%$ C25 up to C35 and $1.67 \%$ C 35 and other organic compounds.

BTEX and hydrocarbons shorter than C10 were under detection limit of 0.01ppm. An initial C:N:P ratio of 100:5:1 was selected based on previous studies (9). For this purpose, $12 \mathrm{~g}$ of urea dissolved in distilled water were added in three fractions every ten days during the first 30 days. The fractionated addition of urea was done to avoid partial loss of nitrogen and fungicidal effects of ammonia gas product of the microorganisms urease conversion over urea $(11,12)$. Control reactor consisted of $70 \mathrm{~kg}$ of $100 \%$ contaminated soil placed in a bin. The aeration by rotation of the barrel was daily during the first 45 days of treatment to assure oxygen provision and then on days 75, 90 and 210. Subsequently, the mixture was allowed to mature without rotation up to day 360 .

Systems and environmental temperature, humidity content, $\mathrm{pH}$ and Aerobic hydrocarbon degrader microorganisms were measured every two days up to day 14 , on a weekly regime up to day 45 and then on days 135, 210 and 360 of the process.

Petroleum hydrocarbon analysis were performed on samples of the initial components individually and on both systems taken on days $0,45,75,90,210$ and 360 of the process.

An average sample of $200 \mathrm{~g}$ was obtained by mixing five aliquots of approximately $40 \mathrm{~g}$ extracted from different points of the reactor. Collected and mixed, samples were dried at room temperature for $24 \mathrm{~h}$ and then sieved ( $2 \mathrm{~mm}$ diameter openings). All analytical determinations were performed in duplicate.

\section{ANALYTICAL METHODS}

For every sample, a $10 \mathrm{cc}$ aliquot was mixed with $50 \mathrm{ml}$ of distilled water for five minutes before the $\mathrm{pH}$ was measured with an electrode. Approximately $10 \mathrm{~g}$ of sample was placed in a preweighed porcelain capsule and dried at $105^{\circ} \mathrm{C}$ for $24 \mathrm{~h}$. The capsule with sample was weighed before and after drying to obtain the percent humidity mass. Distilled water was stirred with soil and brought to saturation. Subsequently, the saturation point was determined as percent humidity mass. Total nitrogen was determined following a micro-Kjeldahl analysis (5) with minor modification for soils. Absorbed phosphorous was determined according to Bray \& Kurtz (8). Total HC were extracted with dichloromethane by Soxhlet to conduct further detailed chemical analyses. A 20g sample was mixed with $5 \mathrm{~g} \mathrm{Na}_{2} \mathrm{SO}_{4}$ and $10 \mathrm{~g} \mathrm{MgSO}_{4}$. Once all the residual moisture had been absorbed by the $\mathrm{MgSO}_{4}$, the mixture was pulverized and placed in a paper extraction thimble. The top of the thimble was filled with glass wool. The HC were extracted at a rate of 20 cycles $\mathrm{h}^{-1}$ for $4.5 \mathrm{~h}$. Fifteen grams of silica gel were added to the extraction solvent in a stoppered container and was mixed continuously for $10 \mathrm{~min}$. The solvent was then filtered through glass wool, placed in a clean pre-weighed porcelain capsule and evaporated. The capsule was dried at room temperature for $24 \mathrm{~h}$ and weighed to obtain the mass of total extract by gravimetry (GR). A simulated distillation of the extract was performed with the aim of determining the amount of residue at $320^{\circ} \mathrm{C}$. This fraction is comprised of those compounds that remain in the chromatographic injector at 
$320^{\circ} \mathrm{C}$. Subsequently, gas-liquid chromatography analyses with flame ionization detection GC-FID were performed using a Clarus 500 Perkin Elmer chromatograph fitted with a moderately polar $30 \mathrm{~m}$ column (Perkin Elmer). The column temperature was programmed at an initial temperature of $45^{\circ} \mathrm{C}$ for $5 \mathrm{~min}$, then increased at $10^{\circ} \mathrm{C} \mathrm{min}^{-1}$ to $300^{\circ} \mathrm{C}$ and held there for $40 \mathrm{~min}$. Carlo Erba brand calibrators were used as markers for linear hydrocarbons from C6 to C20. ASTM D7169-5 norm (7) was followed as reference.

BTEX and benzene isomers were determined using a Clarus 500 Perkin Elmer gas-chromatograph equipped with a mass selective detector (GC/MS) and automatic Headspace sampler. A 30 m moderately capillary column HP5 type was used working isothermically at $50^{\circ} \mathrm{C}$. Specific ions were used to quantify the aromatic compounds up to C9. EPA Method 8260 B SW846 norm (18) was followed as reference.

Culturable hydrocarbon degrading bacteria were enumerated by standard plate technique with appropriate mineral media (12) using $10 \%$ (vol/vol.) diesel fuel as the sole carbon source.

\section{RESULTS AND DISCUSSION}

\section{Evolution of the operational variables of the system}

The control of temperature was of great concern for our experiment, considering it is a fundamental parameter for control of the activity of the biological process.

Fig. 1 shows the temperature variation of the mixture soilapple filter cake inside the reactor and room temperature during the length of the experiment. An important difference can be appreciated during the first 23 days, which correlated with a change in the physical structure of the mixture, due to the fast degradation of apple filter cake. A strategy of temperature control between $40^{\circ} \mathrm{C}$ and $45^{\circ} \mathrm{C}$ would seem to be appropriate for the bioremediation of $\mathrm{PAH}$-contaminated wastes since it allows for the maximum microbial diversity to be expressed for both,

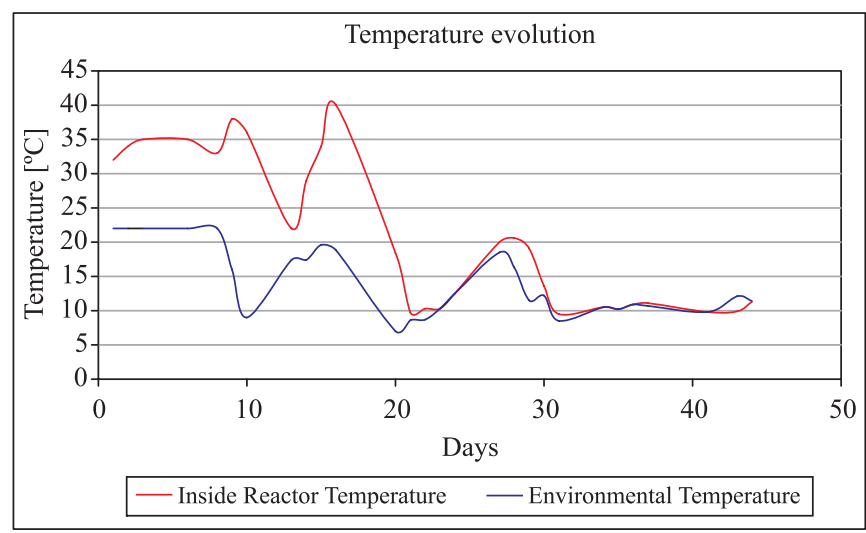

Figure 1. Inside reactor and environmental temperature evolution during the biological process. bacteria, actinomycetes, and fungi (4). On this base and considering the increase in the microbial population, we can accept the temperature range reached of $32^{\circ} \mathrm{C}$ to $36^{\circ} \mathrm{C}$ for eleven days as acceptable for the benefit of our objectives.

Fig. 2 shows that in spite of the changes of temperature, the hydrocarbon degrader microbial population stayed in the order of $10^{8} \mathrm{cfu} \mathrm{g}^{-1}$ soil representing an extension of the active phase of the process up to day 40 . On day 210 descended to the order of $10^{6} \mathrm{cfu} \mathrm{g}^{-1}$ soil, which is still a significant quantity of active $\mathrm{HC}$ degrader biomass.

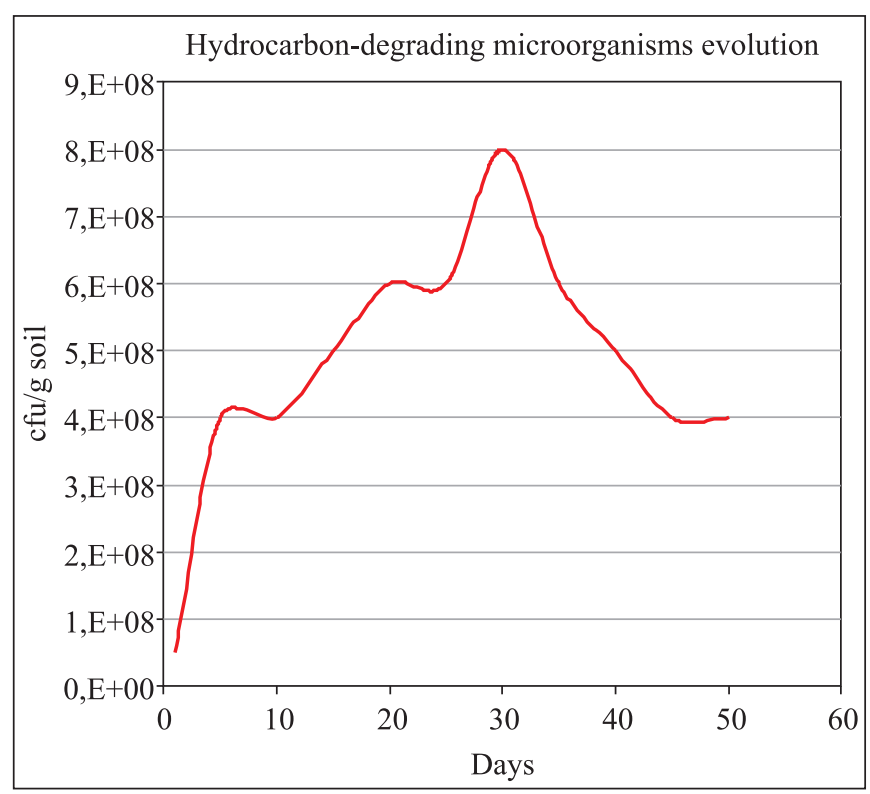

Figure 2. Numbers of Hydrocarbon-degrading microorganisms during treatment.

It is known that the content of cellulose, hemicellulose, lignin and proteins in crop residues influences their own initial decomposition rate. In our system, the apple filter cake exerted a positive effect that increased the microbial population by two orders of magnitude. The reasons of this phenomenon could be that apple filter cake acts as a nutrient supplier and physical conditioner contributing to increased oxygen diffusion and mineral nutrient availability, as well as carbon source and mechanical support surface for bacterial adsorption. A noticeable change in soil structure, aspect and odour, alike a garden soil was observed after treatment compared to control soil. The improvement of soil physicochemical characteristics probably accelerated microbial adaptation and selection and provided additional microorganisms, which contributed to metabolise or maybe cometabolise contaminant hydrocarbons. Furthermore, the contribution of organic matter to soil is generally accepted as a fundamental factor of fertility because its contribution with 
essential nutrients and improvement of physical conditions $(10,24)$. The decrease of the biological parameters after day 40 could probably be attributed to a reduction in nutrients and carbon source bioavailability, to hydrocarbons adsorption to apple filter cake material and soil or to toxic effects produced by residual petroleum fractions $(1,16,19)$.

Moisture content of the mixture remained between 16.28\% and $17.12 \%$ up to day 45 , which corresponds to approximately $45 \%$ to $50 \%$ saturation. The saturation point of the soil was determined to be approximately $35 \%$ moisture by weight of soil. This is consistent with the literature which suggests optimum moisture content for biodegradation of hydrocarbons in soil of approximately 40 to 48 percent of soil saturation $(23,25)$. Nevertheless, our data differed from the majority of previous studies that recommended the maintenance from $30 \%$ to $80 \%$ $(3,9,15,19)$. The difference in optimal moisture content among these studies may be attributed mainly to the scale of work and thus the environmental conditions prevailing in the reactors. Fresh apple filter cake had a moisture level of $86 \%$ and the resultant level in the composting mixture with soil, was enough to avoid compaction and leachates formation. Thus, this moisture range let to the maintenance of aerobic conditions. Besides, with the course of the process, apple filter cake physical characteristics changed becoming a good bulking agent, what further improved the aeration of the process.

Hydrocarbon mineralization is favoured by near neutral $\mathrm{pH}$ values and where it has been shifted away by manmade changes, biodegradability is likely to be impaired (17). The addition of $\mathrm{Ca}(\mathrm{OH})_{2}$ was efficient to maintain $\mathrm{pH}$ values between 7.2 and 7.6 during the complete process, providing a suitable media for microbial growth.

\section{HYDROCARBON ANALYSIS}

In the experimental reactor a slight difference among the total hydrocarbon content along the process $(41,000 \mathrm{ppm}$ in the initial contaminated soil and control reactor, $39,000 \mathrm{ppm}$ for the mixture at day 75 and $42,000 \mathrm{ppm}$ at the end of the process) was observed, which could be attributed to sampling and analytical variations. Under these considerations, $40,000 \mathrm{ppm}$ is considered constant during the process (Table 1).

A diminution of the shorter and the appearance of longer chain compounds can be observed. This phenomenon is also evident in the physical aspect of the Soxhlet extracts. Those obtained at initial stages of the process showed aspect and behavior of oil while the extracts obtained at later stages demonstrated a proportional increase in chain length behaving as a hard wax.

Based on these results a transformation of low molecular weight (GRO and DRO) into heavier paraffin molecules is demonstrated. Apple filter cake has light paraffin content of low molecular weight and an important paraffin content of high molecular weight (greater than C28). These paraffins contributed by apple filter cake to the mixture are of botanical origin and with the evolution of the process, its concentration increases to expenses of the natural humification process and of the fractions GRO and DRO that practically disappear. This phenomenon of residues formation could be interpreted as a result of the microbial activity by incorporation of metabolites into the organic soil matrix. With this hypothesis we reinforce that of Kästner et al. (14) who worked with $\left({ }^{14} \mathrm{C}\right)$ anthracene and demonstrated that the microbial activity produces covalently bound metabolites that become integral parts of humic matter which cannot be further identified.

Low molecular weight hydrocarbons are the main health risk factors in petroleum hydrocarbon mixtures (6). In this experiment, BTEX and other light hydrocarbons up to $\mathrm{C} 10$ were under detection limits before and after the process. To evaluate the performance of the process, the analysis was focused on lighter paraffin chromatographic fractions, what showed a diminution of hydrocarbons from $2.95 \%$ (GRO, DRO and RRO up to $\mathrm{C} 35$ ) to $1.39 \%$ in 90 days of treatment and to $1.16 \%$ after the maturation phase. The noticeable diminution of low molecular weight hydrocarbons content by the composting process encourages us to consider the technique as a valuable tool for bioremediation.

Table 1. Composition of chromatographic fractions of dichloromethane extractable hydrocarbons.

\begin{tabular}{lcccccc}
\hline \multicolumn{1}{c}{ Components } & $\begin{array}{c}\text { Dry soil } \\
\text { Day 0 }\end{array}$ & $\begin{array}{c}\text { Dry mixture } \\
\text { Day 45 }\end{array}$ & $\begin{array}{c}\text { Dry mixture } \\
\text { Day 90 }\end{array}$ & $\begin{array}{c}\text { Dry mixture } \\
\text { Day 90 }\end{array}$ & $\begin{array}{c}\text { Dry mixture } \\
\text { Day 90 }\end{array}$ & $\begin{array}{c}\text { Control reactor } \\
\text { Day 360 }\end{array}$ \\
\hline GRO(\%) & 0.13 & 0.04 & 0.02 & 0.01 & 0.01 & 0.12 \\
DRO (\%) & 2.59 & 1.97 & 0.96 & 0.63 & 0.35 & 2.59 \\
RRO up to C35 (\%) & 0.23 & 0.32 & 1.16 & 0.75 & 0.80 & 0.25 \\
RRO sup to C35 and others (\%) & 1.15 & 1.67 & 1.86 & 2.51 & 3.00 & 1.14 \\
\hline
\end{tabular}

GRO, Gasoline Range Organics i.e., C6 to C10-12; DRO, Diesel Range Organics i.e., C8-12 to C24-26 and RRO, Residual Range Organics i.e., $\mathrm{C} 25$ to $\mathrm{C} 35$; Chromatographic fractions are expressed in weight percentage on the gravimetric determination of dichloromethane extractable compounds. 
The success of the composting process depends not only on decreasing chemical concentrations, but also on the soil's suitability to support the normal soil fauna and flora (14). In this sence, ecotoxicity tests on the product would be relevant to prove the productivity of the soil after the bioremediation treatment.

As a bioremediation alternative, the utilization of apple filter cake was successful considering that the hydrocarbon fractions of environmental concern were noticeable reduced. Thus, its use of for amelioration of hydrocarbon contaminants promotes soil sustainability and re-use.

\section{ACKNOWLEDGEMENTS}

Authors wish to thank Lic. María Esther Barbeito from Instrumental Analysis Laboratory, Engineering Faculty, National University of Cuyo for her analytical assistance and valuable comments.

\section{RESUMO}

\section{Bioconversão de hidrocarbonetos de petróleo no solo pelo uso de bagaço de maçã}

O objetivo deste estudo foi investigara viabilidade de aplicação de bagaço de maçã, um resíduo do processamento de frutas, para melhorar a biorremediação de solo contaminado com petróleo. Para estudar a bioconversão de compostos xenobióticos pela população microbiana naturalmente presente empregou-se um sistema de barril rotativo. O solo havia sido acidentalmente contaminado com um total de hidrocarbonetos de petróleo na concentração de 41.000 ppm. Embora esse valor tenha se mantido durante o processo, a intervenção microbiana ficou evidenciada através da transformação de frações do petróleo. Assim, as frações de risco para o meio ambiente (GRO, Gasoline Range Organics, i.e., C6 a C10-12; DRO, Diesel Ramge Organics, i.e. C8-12 a C2426 e RRO, Residual Range Organics, i.e. C25 a C35) foram significativamente reduzidas de $2,95 \%$ para $1,39 \%$. Por outro lado, frações mais pesadas, acima de $\mathrm{C} 35$, e outros compostos orgânicos aumentaram de $1,15 \%$ para $3,00 \%$. A diminuição notável do conteúdo de hidrocarbonetos de baixo peso molecular e conseqüentemente do risco ambiental por esse processo, além da melhoria das características físicas do solo, são resultados promissores para uma futura aplicação em grande escala.

Palavras-chave: bagaço de maça, bioconversão, biorremediação, solo contaminado com petróleo

\section{REFERENCES}

1. Ahn, I.-S.; Lion, L.W.; Shuler, M.L. (1996). Micro scale-based modelling of polynuclear aromatic hydrocarbon transport and biodegradation in soil. Biotechnol. Bioeng., 51, 1-14.
2. Antizar-Ladislao, B.; Lopez-Real, J.; Beck, A.J.; (2005). Laboratory studies of the remediation of polycyclic aromatic hydrocarbon contaminated soil by in-vessel composting. Waste Manage, 25, 281289

3. Antizar-Ladislao, B.; Lopez-Real, J.; Beck, A.J. (2006). Degradation of polycyclic aromatic hydrocarbons (PAHs) in an aged coal-tar contaminated soil under in-vessel composting conditions. Environ. Pollut. In press

4. Antizar-Ladislao, B.; Lopez-Real, J.; Beck, A.J. (2004). Bioremediation of polycyclic aromatic hydrocarbon (PAH)-contaminated waste using composting approaches. Critical Reviews in Environ. Sci. Technol., 34, 249-289.

5. APHA-AWWA-WPCF (1998). Method 4500- $\mathrm{N}_{\text {ORG }} \mathrm{B}$ of Standard Methods for the examination of Water and Wastewater Micro Kjeldahl. Modified.

6. ASTM (The American Society for Testing and Materials) (1995). Standard Guide for Risk-Based Corrective Action Applied at Petroleum Release Sites E 1739-95. p. 14. PA 19428-2959, United States.

7. ASTM D7169-05 Standard Test Method for Boiling Point Distribution of Samples with Residues Such as Crude Oils and Atmospheric and Vacuum Residues by High Temperature Gas Chromatography

8. Bray and Kurtz, Soil Sci., 59: 39 (1945). Determination of phosphorous fluoride extractable. In: Jackson M.L., Chemical analysis of soils, (pp. 223-230). Omega S.A. Ed., Barcelona, 1976. ISBN: 84-282-0261-3.

9. Beaudin N.; Caron, R.F.; Legros, R.; Ramsay, J.; Ramsay, B. (1999). Identification of key factors affecting composting of a weathered hydrocarbon-contaminated soil. Biodegradation, 10: 127-133.

10. Bohn, H.L.; McNeal, B.L.; O'Connor, G.A. (1993). Química Del Suelo. Cap.5. Materia Orgánica. p. 155-173. Ed. Limusa México D.F. Primera Edición. ISBN: 968-18-4431-9.

11. Chaillan, F.; Chaîneau, C.H. ; Point, V.; Saliot, A.; Oudot, J. (2006). Factors inhibiting bioremediation of soil contaminated with weathered oils and drill cuttings. Environ. Pollut. In press

12. Chaillan, F.; Le Flèche, A.; Bury, E.; Phantavong, Y.; Grimont, P.; Saliot, A.; Oudot, J. (2004). Identification and biodegradation potential of tropical aerobic hydrocarbon-degrading microorganisms. Res. Microbiol., 155, 587-595.

13. Dangerous Residues Law of Argentina, National Law No24051.

14. Juvonen, R.; Martikainen, E.; Schultz, E.; Joutti, A.; Ahtiainen, J.; Lehtokaria, M.; (2000). A battery of toxicity tests as indicators of decontamination in composting oily waste. Ecotoxicol. Environ. Saf., 47, 156-166.

15. Kästner, M.; Streibich, S.; Beyrer, M.; Richnow, H.H.; Fritsche, W. (1999). Formation of bound residues during microbial degradation of $\left[{ }^{14} \mathrm{C}\right]$ Anthtacene in Soil. Appl. Environ. Microbiol., 65 (5), 18341842 .

16. Löser, C.; Seidel, H.; Hoffmann, P.; Zehnsdorf, A. (1999). Bioavailability of hydrocarbons during microbial remediation of a sandy soil. Appl. Microbiol. Biotechnol., 51, 105-111.

17. Margesin, R.; Schinner, F. (2001). Biodegradation and bioremediation of hydrocarbons in extreme environments. Appl. Microbiol. Biotechnol., 56: 650-663.

18. Method 8260B, 1996. Volatile Organic Compounds by gas chromatography/mass spectrometry (GC/MS). Revision 2. SW846

19. Molina-Barahona, L.; Rodríguez-Vázquez, R.; Hernández-Velasco, M.; Vega-Jarquín, C.; Zapata-Pérez, O.; Mendoza-Cantú, A.; Albores, A. (2004). Diesel removal from contaminated soils by bio stimulation and supplementation with crop residues. Appl. Soil Ecol., 27, 165175 .

20. Namkoong, W.; Hwang, E.Y.; Park, J.S.; Choi, J.Y. (2002). Bioremediation of diesel-contaminated soil with composting. Environ. Pollut., 119, 23-31. 
21. Nitschke, M.; Ferraz C.; Pastore, G.M. (2004). Selection of microorganisms for biosurfactant production using agroindustrial wastes. Braz. J. Microbiol., 35: 81-85

22. Rivera-Espinoza, Y.; Dendooven, L. (2004). Dynamics of carbon, nitrogen and hydrocarbons in diesel-contaminated soil amended with bio solids and maize. Chemosphere, 54, 379-386.

23. Saberiyan, A.G.; Macpherson, J.R.; Andrilenas, J.S.; Mmre, R.; Ruess, A.J. (1996). A bench-scale biotreatability methodology to evaluate field bioremediation. Monitoring and verification of bioremediation - Battelle Press, 3 (5) 185-191.
24. Semple, K.T.; Reid, B.J.; Fermor, T.R. (2001). Impact of composting strategies on the treatment of soils contaminated with organic pollutants. Environ. Pollut., 112, 269-283.

25. Stegmann, R.; Lotter, S.; Heerenklage, J. (1991). "Biological treatment of oil-contaminated soils in bioreacton." On-site Bioremediation: Processes for Xenobiotic and Hydrocarbon Treatment, Butterworth - Heinemann Stoneham, M.A.; Hinchee, R.E.; Oflenbutiel, R.E. (Eck.), 188-208.

26. USEPA (1998). An Analysis of Composting as an Environmental Remediation Technology, EPA530-R-98-008

27. Van Gestel, K.; Mergaert, J.; Swings, J.; Coosemans, J.; Ryckboer, J. (2003). Bioremediation of diesel oil-contaminated soil by composting with bio waste. Environ. Pollut., 125, 361-368. 